\title{
AFRICAN CONTRIBUTION TO CHRISTENDOM *
}

Tokumboh Adeyemo

Centre for Contextual Hermeneutics

\begin{abstract}
In this article Christianity in Africa is deemed to be making six contributions to world Christianity. Although the church in Africa is poor, it has much to offer by way of its holistic world-view, people-centredness, community orientation, expressive worship, adaptability in mission, and the will to cooperate. The latter is seen particularly in the flourishing of the ecumenical association of evangelicals in Africa.
\end{abstract}

'Poor, yet making many rich' (2 Cor 6:10).

There is a myth out there that asserts that since the church in Africa is financially poor, there isn't anything it can offer to the rest of the church worldwide. This is untrue. I shall delineate some of the African religious wealth the church in Africa can contribute to Christendom.

\section{A religious world-view}

First on the list is a religious outfit for life. By this we mean the basic world-view or grid through which people perceive and interpret their world: pre-suppositions that shape people's attitude and influence their conduct. It has been said that a worldview is like a referee in a football match. He may seem unimportant and hardly recognized, but in reality he decides the game.

Unlike the Western thought of the world as a mechanism which gave birth to the modern evolutionary theory and its corollary, namely secularistic materialism, the basic African world-view is religious. By an African - sophisticated or simple, literate or illiterate, urban or rural - a reality is perceived and events are interpreted through religious lenses. Religion is not just an aspect of life, but all of life. One of the implications of this view is that Africans don't draw a dichotomy between the sacred

\footnotetext{
* Paper read at the dialogue between Afrikaner theologians and other African theologians in Nairobi, Kenya, 6-13 April 1991.
} 
and the secular, for all belongs to God. An African churchwoman carries her faith into the public bus; to the market place; to the court of justice; and to the corridor of power; from Sunday to Saturday. Prayers are performed in her public schools. Biblical teachings of the Lordship of Christ lends support to this integral view, 'for the earth is the Lord's and the fullness therein'.

In an age of increasing secularism, the church in Africa can help the church worldwide recapture a theistic religious outlook to life.

\section{People-centredness}

Secondly, the church in Africa can help to restore a philosophy of peoplecentredness. Africans believe that things (including time) are made for the benefit of man. Although the weakness of this attitude (such as not keeping time or irresponsible use of nature) is to be discouraged, the fact remains that human beings are of ultimate value of all of God's creation. Only that which is done to make humanity more humane can be called development and not flashy cars nor skyscrapers.

In its outreaches or missions, the church in Africa places emphasis on people and not on programs; on love and not on numbers. Loving concern and care for people will serve as an antidote for materialism.

\section{Community-orientation}

Side by side with the philosophy of people-centredness is a social phenomenon of community orientation rather that individualism. An African proverb says: 'I am, because we are'. An African is not an individual in a technical sense as an individual will be in the West. Rather, an African is a being-in-community. He or she is a part of an organic whole. This is why blood ties wax strong and can be abused (as in tribalism). Overall, the Church in Africa is a family, an extended family of love and care. It is a social unit where needs are shared; pains are borne together; and love is spread. This fact led Welbourn and Ogot to entitle their book A Place to Feel at Home, which is a study of two African independent churches in Western Kenya.

\section{Expressive worship}

By and large, Africans are warm and expressive in worship. In our traditional religions, a stage performance where one or two dominate the service with a passive audience is atypical. Rather, mutual participation and active involvement of both the leaders and the led is the norm. Unfortunately, at the introduction of Christianity to the continent, worship was patterned after that of the founding mission-related churches such as Anglican, Roman Catholic, Presbyterian, Methodist, Baptist, etc. Those who brought the Book understood the rules. It was logical therefore for the early church in Africa to look like a caricature of the home churches of their founding missions. This element of foreignness prompted the nationalists to accuse Christianity as being a 'white man's religion'. 
Traditionally, organized corporate worship was rare. Usually associated with cycles of life and farming seasons such as initiation and harvest, corporate worships are always festive and joyous. They last for hours and sometimes days. Both adherents and non-adherents join in such public worship which is often used as a means for propagation and 'conversion'. Of course there are taboos to observe. However, traditional worshippers are not as inhibited and confined to benches (a classroom syndrome) as in the Christianity that came to us. Neither will one find such musical instruments as guitar, piano, organ and violin which, according to one African scholar, cannot wake up a sleeping demon. As long as the minimum rules are followed, there seems to be abundant freedom in African worship. This may explain in part the general charismatic flavour in worship of all denominations in postindependent Africa.

As one ponders on Christ's worship in spirit and truth, and Paul's worship with the spirit and mind, one cannot help but think of African spontaneity and exuberance, tempered by taboo instruction. The Spirit and the Word must go together in worship. The Spirit without the Word may burn worshippers, while the Word without the Spirit may drown them. The church in Africa can help restore this happy balance.

\section{Adaptability in mission}

A fifth area of contribution to consider is that of cultural adaptability. The history of Africans in diaspora (e g North and South America and the West Indies) has demonstrated that Africans don't break easily under adversities. They have not only outlived sugar-cane plantations, but also have made homes out of a 'wilderness'. This quality of toughness and stretchability is essential for cross-cultural missions. Wherever one goes, be it the extremely cold country of Greenland or the isolated island of New Zealand, one finds Africans in pursuit of education or hunting for treasures. Such energy can and must be harnessed for world missions.

On the labour market, it is still cheaper to maintain African missionaries than their Western counterparts. Living a simple lifestyle is a matter of necessity for many an African missionary, whose financial support from home is often non-existent at worst, or irregular at best. It is appropriate to describe them as 'faith missionaries', for indeed, that is what they are. I know of a case of a Nigerian missionary lady in Kenya who had to make 'tie and dye' clothes in order to make ends meet. And this is not an isolated case at all.

In an age when raising missionary support and deputations have become a big industry, the simplicity of missionary endeavour as practised by Africans take us back to the time of Jesus with all of its weakness and vulnerability' but also faith in God who said 'Lo, I am with you always to the end of the age'.

If the church in Africa can help us return to the biblical worship and to the simplicity of faith in cross-cultural missions, then her material poverty is more than compensated for. 'Poor, yet making many rich' - how true! 


\section{The will to cooperate}

Christianity came to Africa in fragments. The invading missionary groups propagated the Gospel with an accent on their own particular denominational emphasis. Missionaries of the Church and Missionary Society (CMS) from England started Anglican churches patterned in every regard after the Church of England. The same goes for the Presbyterians, who took after the Church of Scotland, and so on.

The missiological strategy of 'comity', whereby one missionary group worked exclusively in one geographical location and with a particular tribal unit, was, in the long run, a liability to the biblical message of Christian unity. Consequently tribal Christians were produced. To many an African Christian, even today, primary allegiance is to one's tribe and second only to the Christian community. Consider the number of Christian young people who have been forbidden by their parents from marrying Christians who happen to be from another tribe, though the youth were sure of God's guidance. This is a scandal to such passages as: John 17:21-23; Ephesians 2:14-18; 4:1-6; and Galatians 3:28.

In contrast to the divisions and disunity which the missionary agents brought, adherents of any particular traditional deity stuck together, regardless of their tribal and social differences. Take for example, the Yoruba oracular divinity called Ifa (i e god of divination). The adherents and priests of this deity from Nigeria regard and treat themselves as one with the adherents and priests of Kayong' $u$, the spirit of divination among the Ndembu of north-western Zambia. This principle of oneness and togetherness applies to those who practise witchcraft and occultism. Call it unity in the dark.

It puzzles me. It is commonly believed that 'divide and run' is Satan's philosophy. If this is true, one wonders why the church is so fragmented, so polarized and so divided along racial, tribal and social lines even when their theology is the same.

The church in Africa has a contribution to make in the area of believers' unity and cooperation for world evangelization, but only after her divisions have been healed. In February of this year, there was a week-long united community crusade organized jointly by two of the leading congregations in Nairobi, Kenya: the Nairobi Baptist Church and the Nairobi Pentecostal Church. Crusade teams such as the choir and the counsellors were jointly run. The resulting great harvest was not only a glory to God, but a powerful demonstration of the effect of Christian unity as well.

Within the family of the Association of Evangelicals of Africa and Madagascar (AEAM), there are over one hundred and eighty-eight different denominations and missions agencies, representing over fifty million evangelical believers sharing a common theological platform. In essential non-negotiable theological affirmations there is agreement. In the non-essential matters such as form of baptism or church polity, there is toleration. In all things, the rule is speaking the truth in love. The AEAM motto says it well:

Coming together is a beginning

Staying together is progress 
Thinking together is real unity

Working together is success.

To these evangelicals throughout the continent, unity is not a mere password. A number of very essential programmes and projects, including graduate schools of theology, an accrediting council for theological education, production of Sunday school materials, evangelism and missions, leadership training, communication strategy and skills training and relief and development is being sponsored by the AEAM for the benefit of its entire constituency.

Considering the size of the task before it (well over $40 \%$ of the world's population is still unreached); the seriousness of the barriers on her way; and the satanic opposition and schemes, the church cannot afford to be divided and polarized. Together the church must rise (east, west, north and south) as one man, to devastate the kingdom of darkness. When this happens, the world will know and believe that the Father has sent His Son to save the world. 